\section{B A Institute of \\ yk Business Administration \\ तर Karachi \\ Leadership and Ideas for Tomorrow}

Article 4

Volume 3 Issue 1 January-June 2008

$1-1-2008$

\title{
Institution of bureaucracy and the conflict in South Asia
}

Huma Baqai

Institute of Business Administration, Karachi, Pakistan

Follow this and additional works at: https://ir.iba.edu.pk/businessreview

Part of the Social and Behavioral Sciences Commons

c) (i)

This work is licensed under a Creative Commons Attribution 4.0 International License.

\section{Recommended Citation}

Baqai, H. (2008). Institution of bureaucracy and the conflict in South Asia. Business Review, 3(1), 23-32. Retrieved from https://doi.org/10.54784/1990-6587.1130 


\title{
ARTICLE
}

\section{Institution of Bureaucracy and The Conflict in South Asia}

\author{
Huma Baqai \\ Institute of Business Administration, Karachi, Pakistan
}

\begin{abstract}
$\mathrm{T}$ he role of bureaucracies is vitally important in the conflict-cooperation balance. Bureaucrates by definition are implementers of policy. This implementation also sometimes graduates to initiation of policies; therefore, it would be appropriate to say that although they are implementers, they also perform a variety of other functions which enhances their role and importance in the functions of the states, particularly bureaucratic states.
\end{abstract}

Max Weber, the earliest proponent of bureaucratic behavior, applauded the bureaucratic mode of political organization as the most advanced and the best form suited to the administration of complex societies. To him, the bureaucratic mode was a clear advance on its predecessors. However, the model is not in practice anywhere. No bureaucracy in the world functions according to the laid down principles, and therefore, what Weber saw as virtues became vices in the eyes of later observers. What was referred to as predictable and regularized, the critics found it to be restrictive. Rules to provide regularized channels had become ends in themselves and not means to other goals. Injecting fresh approaches became difficult because elected leaders could not break the stranglehold that bureaucracies had on policy. The marshaling of expertise to solve difficult problems became a cover for bureaucrats to serve the interest of their own organizations, at the expense of the public and other bureaucracies with which they competed for resources and influence. What for Weber had been the pinnacle of modern political organization had become the logjam in the machinery of government to successor observers.

The factor of permanence associated with the institution of bureaucracy also has relevance to this discourse. Bureaucracies by being the permanent element of the state should have been the most rational component of the government. With politics and politicians being transitionary, do not deal with issues over a stretched period of time. It is the bureaucrats who are the permanent custodians of the nation's goals and aspirations. The bureaucracy, thus is the system which is responsible for assisting the elected representative of the governments for a fair and faithful dealing of public and private transactions. At the same time, rivalries, interdepartmental hostilities, and divisions are common to all the bureaucracies of the world. The competition and the risk of policy failures causing embarrassment, discourage the taking of bold initiatives, or for that matter even supporting them. The infamous red tapism is also a bureaucratic norm. All of this results in conservatism and routine decision making. 
Bureaucratic behaviors do have an impact on foreign policy decisions of the state. It influences particularly in countries and regions where hostilities exist have been observed. For example in the subcontinent, apparently for bureaucracies, security emanates from the status quo and not change. They continue to be essential both to the domestic and foreign policies

\section{BUREAUCRACIES IN SOUTH ASIA}

The institutions of bureaucracy have an important role in the polity of South Asia. The governments of South Asia are highly bureaucratic, almost linear, and lacking constructive pluralism. The colonial mindset and the legacy of civil service seem to linger on even after sixty years of independent existence.

The bureaucracy in the subcontinent is also called Civil Service. One of the earliest demands of the Indian nationalist opinion was to rationalize the structure and function of civil service, to provide a greater share to Indians in the administration of their country. This desirability of civil service of being supportive of the basic goals was transformed into their necessity of being committed to the government of the day. Thus, services were politicized and corrupted right from the onset, partly because the leadership desired it, and partly because the service themselves sought illegitimate favors from the politicians. There was gradual decline in quality, efficiency, and integrity of services even at the higher level. Civil service careers, promotions and postings, job security, all became part of the system of distribution of spoil and patronage.

Another facet is the excessive bureaucracy which is again a colonial legacy. Within the colonial structures, policies were formulated by colonial leaders, and subsequently implemented by civil servants (bureaucrats). However, after independence, bureaucrats performed both roles despite their relative inexperience in leadership. This continues and as a result, the role of policy makers and leaders are not distinct, and are fulfilled by inexperienced bureaucrats. Their role hence is taken to be of immense importance in the conflict- cooperation equation in inter-state relations.

Indian bureaucracy became politicized partly because the political elite desired it, and partly because the services themselves sought illegitimate favors from the politicians. Due to this, the political neutrality norms of the services suffered grievous erosion. The $73^{\text {rd }}$ and $74^{\text {th }}$ constitutional amendments brought in India (in the name of empowering people and decentralizing power) resulted in more centralization and bureaucratization of power because of the constitutional safeguards. Even after almost sixty years of independence, the bureaucrats have not learnt the simple truth of their being citizens first, and only then officers. They are servants and not masters of the people, thus their job is to serve the people, not rule 
over them. Multilevel and multifaceted corruption and red tapism are two major attributes of Indian bureaucracy. Lack of accountability and patronage of corrupt politicians and greedy businessmen have made the Indian bureaucracy a law unto itself. Bureaucrats have created such a steel frame around themselves that even the might of the state can't dismantle it. Decline in quality, efficiency, and integrity of the bureaucracy in concert with constitutional safeguards has given the Indian bureaucracy a formidable stature.

Role of the Indian bureaucracy in conflict and cooperation has been controversial with procedural stringency being a norm. The politicization of it has impacted India's relation with all its neighbors, be it Pakistan, Bangladesh or Nepal. Bureaucracies seem comfortable with the status quo, and resist and oppose change. Unfortunately the Indian bureaucratic mindset and approach towards policy making and issues of governance and conflict resolution emerges as a major impediment in its desire for a prominent role in international affairs. This is propelling India towards revamping its policy of confrontation and coercive diplomacy in the region. There is increasing realization in the Indian leadership and think tanks that bureaucratic inefficiency has to be tackled by downsizing the bureaucracy and also by envisaging regulatory rules for the remaining one. However, this particular focus is for the domestic role of the bureaucracy, or maybe the bureaucratic delays caused on the economic front where foreign investors complain about Indian persistence with unnecessary regulations.

National security debates in India have also been impaired by the generalist nature of the Indian bureaucracy. The bureaucracy suffers from the tradition of Vikramaditya throne, whereby wisdom and expertise are not acquired through dedication and toil, but are embedded in the chair a person occupies. The conceptual reality of this is that permanent bureaucracy becomes too career-oriented to offer rational policy options to the changing leadership. The bureaucracy because of its limited vision and expertise is unable to demonstrate any imagination so essential to develop the new thinking in the conflict-cooperation balance of the region. The religious zealots, extreme nationalists, and masses continue to mistrust the bureaucracy and have no confidence in them to protect vital national interests. The bureaucracy on the whole is viewed as a corrupt institution.

Since early 1920s, Jawahar lal Nehru remained the undisputed architect, articulator, and practitioner of Indian foreign policy. His virtual monopoly over Indian foreign policy decisions not only lasted for over 40 years, but continues to dominate even after his death in 1964. On the domestic front, he did face opposition but never on his stance on external relations. None of his colleagues, contemporaries, or critics had any inclination to seriously confront his foreign policy. In the words of Stephen Cohen, "Even though Nehru encouraged debates on foreign policy issues, few politically strong figures could challenge him on the floor of the Parliament--- Nehru was a one-man policy, planning staff and coordinator, as well as the source of major 
initiatives that put India on the world's diplomatic map----there was no need for institutional development in foreign policy when Nehru combined both expertise and political power." and he completely dominated the foreign and security policies with limited consultations with his colleague and subordinates. The dual role as India's foreign minister eroded any room for consensus building. This Nahruvian tradition continued for a long time and foreign policy has remained the exclusive prerogative of the prime minister who often doubles as the minister of external affairs as P.V Narasimhma Rao, I.K. Gujral and Atal Behari Vajpayee.

Another important tendency which over the years has contributed to the centralization of decision making with the prime minister is the working of the prime minister with a small group of advisers, though the decision-making is supposed to be the joint responsibility of the prime minister and his cabinet. The handpicked group of advisors alone was a part of and privy to the sensitive strategic decisions taken by prime minister, later formally endorsed by the cabinet. Since they were answerable and accountable only to the prime minister, their advice and suggestion tended to circumvent normal democratic institutions as well as parliamentary oversight. Indra Gandhi and Rajiv Gandhi continued with this practice. Vajpayee was also known for independent on the spur foreign policy decisions. J.N. Dixit in his memoirs, talks about how Foreign Minister Narishma Rao was not favorable to the idea of Indo-Sri Lanka accord of 1997. He made three points about the whole process of negotiations. First, India should not rush into this agreement. Second, it should carefully consider the wisdom of being direct signatories to this agreement. He was of the view that Sri Lankan Tamils should sign the agreement with Sri Lankan government and we should just be guarantors. Third, he suggested that India must very carefully assess whether the willingness of the LTTE and Sri Lankan government to come to an agreement was based on a genuine desire for peace and a durable settlement, and not just an interim tactical move. Suggestions of the then Foreign Minster were totally ignored and Rajiv Gandhi went ahead with the controversial accord.

Sensitive national decisions, especially in the nuclear arena, were also confined to the prime minister, with the rest of the political leadership, the armed forces, and the bureaucracy remaining completely out of the process. The Foreign Ministry had no knowledge of Indian weaponisation program and was not informed about the goal of India acquiring a full balanced nuclear deterrence capability. The two examples definitely point towards a tradition of bypassing institutions, as well as towards institutional inadequacy in India. The institution of bureaucracy falls short both on the domestic and foreign policy front. The Indian bureaucracy on the whole is subordinate to the office of the Prime Minister, especially in matters of national security. It, however, does perform the usual role of a bureaucracy in a bureaucratic polity, where in routine decision-makings; focus on status quo is maintained and any innovative thinking or bold initiatives for conflict resolution are prevented. 
In Pakistan, bureaucracies agitate more controversies than any other component of the ruling establishment. The tradition of a strong centralized administration and an efficient framework of services, a legacy of the British, could have been an asset for the newly born state. Unfortunately, it became politicized immediately because of the constant interference by politicians and the military. The bureaucratic-militaryelite are at the core of Pakistan's power configuration. The military and bureaucracy are the principle institutions. Their elites are relatively small, cohesive, share similar political attitudes, and enjoy institutional bases of power. After independence, a new era began in which the role of the bureaucracy expanded rapidly, both horizontally and vertically. In place of law and order, development became the new buzzword. To undertake the development work of a newly formed country, the concept of statutory bodies came into existence. Laws were made to establish specialized bodies with specific objects with a great degree of autonomy, so they may function unencumbered with red tape. This changed the power and role of the bureaucracy radically; however, its traditional mindset was not altered at all.

Bureaucratic attitudes became redundant to contemporary needs in two ways. First, the primary orientation was not altered from serving the masters to serving the masses. Second, Indian civil services were performance oriented; in that their primary role was to execute authority and justice on the beaten track. The institutional decay set in, which depicts itself by virtue of being heavily politicized and unable to provide basic public service, because the bureaucracy is fully aware that the political superiors are dependant on it for policy advice and administration, which is the key for their own political sustenance.

The shift in the institutional balance of power in Pakistan in favor of the military and bureaucracy is interplay of domestic, regional and international, factors. They include the institution of strong central government, problem of asserting authority over provinces, and most critically, the defense imperative of a state besieged by external and internal threats, especially the initiation of hostilities with India over Kashmir. This allowed military-bureaucracy nexus deliberately and systematically weakening the political process by exploiting the rivalries among politicians on one hand, and manipulating their connection with the centers of the international system in London and Washington. ${ }^{16}$ Pakistan even bartered away its autonomy in foreign affairs to serve the interests of the military bureaucratic oligarchy.

The Pakistan's polity emerges as a textbook case of bureaucratic authoritarianism. The prevalence of this approach in the polity of Pakistan can be gauged by the following:

- Postponing the distribution of resources or even reversing it in order to foster economic growth. The Ayub Khan's one unit and more recently the controversy and conflict over the allocation of NFC Awards, water distribution and storage (Kalabagh Dam) are examples of it.

- The desire to create a more efficient, internationally competitive economy and cultivating international economic actors, partners in the development 
model. In the past, policies followed by General Ayub Khan which created the dominance of twenty-two families in Pakistan followed this pattern. Pakistan's continues with this dependence on international monetary agencies (IMF, World Bank and the Asia Development Bank). The macroeconomic reforms introduced at the behest of these agencies are not always people-centric and inclusive.

- Attempts to control or destroy movements which would undermine or resist such policies. Bureaucratic authoritarianism thus gets translated into a form of bureaucratic and technocratic military rule that seeks to curtail popular mobilization, and is built on political coalitions and policy orientation that entails strong ties to international economic actors. It is a form of modern rather than traditional authoritarianism and has a major bureaucratic dimension.

After practically sixty years of Pakistan's existence, civil and military bureaucracies have had a very important role in the making and implementation of policies, both foreign and domestic. From devising development strategies to preparing fiscal and monetary policies, waging wars, keeping conflicts alive, negotiating foreign assistance, all has been done by senior bureaucrats. Politicians have occasionally barged in, but the impact has been very limited because of implementation constraints. The implementation is the prerogative of the bureaucrats. In Pakistan, the civil and military bureaucracy have always taken all major decisions. The chart below would gives details of the institutional balance in Pakistan

Power Balance in Pakistan

\begin{tabular}{|l|l|l|l|l|l|}
\hline $\begin{array}{c}\text { Time } \\
\text { Period }\end{array}$ & $\begin{array}{l}\text { Democratic } \\
\text { Governments }\end{array}$ & Bureaucracy & Military & \multicolumn{1}{|c|}{$\begin{array}{c}\text { Feudal } \\
\text { Politicians }\end{array}$} & $\begin{array}{c}\text { Religious } \\
\text { Leaders }\end{array}$ \\
\hline $1951-58$ & In name & Real Power & $\begin{array}{l}\text { Supporting } \\
\text { Junior } \\
\text { Partner }\end{array}$ & - & - \\
\hline $1958-69$ & - & $\begin{array}{l}\text { Supporting } \\
\text { Partner }\end{array}$ & Real Power & Supportive & Supportive \\
\hline $1969-71$ & - & Real Power & $\begin{array}{l}\text { Supporting } \\
\text { Partner }\end{array}$ & $\begin{array}{l}\text { West-Wing } \\
\text { Support }\end{array}$ & Supportive \\
\hline $1971-77$ & Real Power & Downsized & $\begin{array}{l}\text { Influence } \\
\text { Curtailed }\end{array}$ & Partners & Neutralized \\
\hline $1977-88$ & - & Restored & Real Power & Partners & $\begin{array}{l}\text { Very } \\
\text { Supportive }\end{array}$ \\
\hline $1988-99$ & $\begin{array}{l}\text { Competitive } \\
\text { Democracy }\end{array}$ & $\begin{array}{l}\text { Supportive } \\
\text { Partner }\end{array}$ & $\begin{array}{l}\text { Influence } \\
\text { Curtailed }\end{array}$ & Partners & Supportive \\
\hline $1999-01$ & - & $\begin{array}{l}\text { Supportive } \\
\text { Partner }\end{array}$ & Real Power & Partners & Supportive \\
\hline $\begin{array}{l}2001-\text { to } \\
\text { date }\end{array}$ & In name & $\begin{array}{l}\text { Supportive } \\
\text { Partner }\end{array}$ & Real Power & Partners & Opposed \\
\hline
\end{tabular}


The security debate and perceptions in Pakistan become more understandable because of the military-bureaucracy nexus. The unilateral focus on external threats and the India-centric security paradigm actually serves the purpose of this elite group. The gradual increase in internal security problems, because of these linear security perceptions, does not get impressed upon the policy makers of Pakistan. It is actually grounded in a strong tradition of the bureaucratic-organizational imperative. The world view of Pakistan is just divided between states that strengthen Pakistan against India and those who do not. Such a classification is convenient from the standpoint of the civil-military bureaucracy that has control over policy-making. The existence of a continued and formidable threat allows policy makers to get away with a simple security plan. This particular skew in policy making provides greater room for sustaining bureaucratic organizational interests, since military security is given precedence over every other agenda. As a result like any post colonial bureaucratic state structure, Pakistan defined security in tangible terms. More specifically, it is defined as an ability to stave-off a military threat from India. Due to the weak political process in Pakistan, the bureaucracy emerges as a major player in the conflict-cooperation equation in the region. The nexus between the military and bureaucracy makes it even more formidable, promoting patterns of conflict rather than cooperation in inter-state relations.

Sri Lanka also inherited a strong framework of civil service at independence. Its composition and nature, however, kept changing. Its merit and political neutrality was compromised because of the ethnicity based civil war in Sri Lanka. The political class in Sri Lanka assumed dominance over the bureaucracy, particularly because of a functioning parliamentary democracy. Nonetheless, politicization of services led to several evils including corruption in administration, overstaffing, and inefficiency. Parliamentary constituencies became more like the fiefdoms of parliamentarians. In effect the role of the civil services in Sri Lanka stands undermined.

In Nepal there is largely uninstitutionalized competition for power. The bureaucracy or civil service hardly exists. The policy making in Nepal suffered because of a total absence of political institutions controlling the bureaucracy. The mechanism of parliamentary control did not grow fast enough and, therefore, the old practices of subservience, unquestioning obedience, sycophancy and personal service continued. The 1990 Constitution thus confers the professional civil service commitment to the principle of bureaucratic neutrality, recruitment by competition on merit, and promotion on grounds of efficiency and seniority has not really evolved.

In Bhutan, there is a policy of self imposed isolation because of its claustrophobic geographical position where larger, richer, stronger, and occasionally antagonistic neighbors have made external relations crucial not only to its survival as an independent state, but also its internal politics. Like any other buffer state, Bhutan has sought security by pursuing a policy of withdrawal from the surrounding world. 
The rigid postures and maximilist position adopted by the bureaucrats and the politicians of the region have been the bane of cooperation. It often serves the purpose of the political leadership under pressure from various lobbies to let the bureaucrats assume a harsher posture, while maintaining their own mild and friendly tone. This tactic is a mark of India-Pakistan relations. This confuses people, provides sustenance to hawks, and causes despair to those interested in peace. For cooperation to happen in the region there is a need for bold initiatives and out of box solutions. The courage to propose and do what has not happened so far. The bureaucracies of the region will have to fall in line. Rampant corruption, which the bureaucracy is a part and parcel can only be eliminated if more transparency, access to information, and accountability is introduced. The protection mechanisms are also to be abolished. Since the violence in South Asia is structural and the bureaucracies are a part of this violence, South Asia call for a radical change to do away structural violence both at inter and intra-state levels.

\section{REFERENCES}

Proponents of the model claim that bargaining among foreign policy bureaucracies is the key to understanding a state's foreign policy output. However, the role of both domestic and international politics cannot be subtracted from the equation.

The term civil service was first coined for the employees of the East Indian Company, who served in departments other than the military.

Subhash C Kashyap, The Political System and Institution Building Under Jawahar lal Nehru (New Delhi: National Publishing House, 1990), p.76.

For a detailed analysis see Bardhan P, The Political Economy of Development in India (New Delhi: Oxford, 1990).

Subash C. Kashyab, Institutions of Governance in South Asia (New Delhi: Konark Publishers, 2000), p.117.

See Muchkund Dubey, Nancy Jetly (eds.) South Asia and its Eastern Neighbors, Building a Relationship in the 21st Century (New Delhi: Konark Publishers, 1999).

Indian trade relations with Nepal, Sri Lanka and Bangladesh are pertinent examples. Investors from the US, Japan, Britain, Israel and Singapore have also voiced concerns about the bureaucratic delays.

VIKRAMADITYA, a legendary Hindu king of Uzjain, who is supposed to have given his name to the Vikram Samvat, the era which is used all over northern India, except in Bengal, and at whose court the " nine gems " of Sanskrit literature are also 
supposed to have flourished. The Vikram era is reckoned from the vernal equinox of the year 57 B.C., but there is no evidence that that date corresponds with any event in the life of an actual king. As a matter of fact, all dates in this era down to the loth century never use the word Vikram, but that of Malava instead, that being the tribe that gives its name to Malwa, The name Vikramaditya simply means " sun of power," and was adopted by several Hindu kings, of whom Chand-ragupta II. (Chandragupta Vikramaditya), who ascended the throne of the Guptas about A.D. 375 , approaches most nearly to the legend.

Subrahmanyam, "Introduction" in Jaswant Singh, Defending India (London: MacMillan Press, 1999), p. XXV.

P. R. Kumaraswamy, "National security: A critique", in P.R. Knmara Swany (ed.), Security beyond Survival (New Delhi: Thousand Oaks, London, 2004), p.27.

Stephen P. Cohen, India: Emerging Power (Washington DC.: The Brookings Institution, 2001), p.69.

Ibid., p. 22.

Vajpayee's invitation to Musharraf to visit Delhi on 24 May 2001.

J.N. Dixit, Assignment Colombo (New Delhi: Konark Publishers, 1998), pp. 119-20.

Subrahmanyan, "Indian nuclear policy" quoted by P.R Kumaraswami "National security: A critique", in P.R Kumaraswami (ed.), Security Beyond Survival (New Delhi: Sage Publications, 2004), pp.31-32.

Ayesha Jalal, Constructing the State, The State of Martial Law: The Origin of Pakistan's Political Economy of Defence (Cambridge: Cambridge University Press, 1990).

The concept of bureaucratic authoritarianism arose from the study of major episodes of authoritarian rule in South America between the 60s and the 80s. Bureaucratic authoritarianism is a type of a military rule interrupted now and then by elected Governments but it is led by the military. This form of rule has been interpreted as distinctively bureaucratic because national leadership was dominated by individuals who has risen to prominence not through political careers but through bureaucratic careers in large public and private organizations, including international agencies and transnational corporations. Decision making is usually technocratic. 
Robert J. Art, "Bureaucratic authoritarianism", in Joel Krieger (ed.), The Oxford Companion to the Politics of the World (New York: Oxford University Press, 1993), pp.96-98.

Ayesha Jalal, "Pakistan's security perspective: Problems of linearity", op. cit. , pp.166-70.

De Silva. K. M. The Bureaucracy in Sri Lanka: Problems of Governance (Dehli: Konark Publishers, 1983), pp.83-98.

Subhash C. Kashyap, Institutions of Governance in South Asia (New Delhi: Konark Publishers, 2000), pp.101-04.

"The only person over whom you have direct and immediate control is your self. The most important ossets to develop, preserve, and enhance, therefore, are your capabilities. And no one can do it for you. You must cultivate the habits of leadership effectiveness yourself and doing so will be the single best investment you'll ever make" 